American Journal of Environmental Sciences 7 (2): 178-182, 2011

ISSN 1553-345X

(C) 2010 Science Publications

\title{
The Impacts of Agricultural Supports for Climate Change Adaptation: Farm Level Assessment Study on Paddy Farmers
}

\author{
${ }^{1}$ Md. Mahmudul Alam, ${ }^{2}$ Mohd Ekhwan bin Toriman, ${ }^{3}$ Chamhuri Siwar, \\ ${ }^{4}$ Rafiqul Islam Molla and ${ }^{5}$ Basri Talib \\ ${ }^{1,3}$ Institute for Environment and Development, \\ ${ }^{2}$ School of Social, Development and Environmental Studies, \\ ${ }^{5}$ School of Economics, Faculty of Economics and Business, \\ Universiti Kebangsaan Malaysia, Selangor, Malaysia \\ ${ }^{4}$ Faculty of Business and Law, \\ Multimedia University, Melaka, Malaysia,
}

\begin{abstract}
Problem statement: The climatic factors are changing very rapidly in Malaysia. To adapt farmers with the changes, government and other external agencies are providing several kinds of supports, but yet the adaptability is not that high. Approach: To analyze the climate change adaptability of the farmers in Malaysia, this study uses primary data that have been collected through questionnaire survey on paddy farmers in the Integrated Agricultural Development Area (IADA), North-West Selangor, Malaysia. Data have been analyzed by using descriptive statistics and ordered regression. Results: Most farmers believe that buying additional fertilizer from market is not important for their current adaptation capability with climate change. As a consequence, $75.3 \%$ of the farmers never used extra fertilizer beyond the fully subsidized quantity. But, $41.4 \%$ farmers agree that government's supports are not enough to adequately cope with climate change. Conclusion/ Recommendations: It is found that sustainability of agriculture and farmers' livelihood are strongly dependent on the external supports. Therefore, farmers' adaptability to climate change needs to be addressed through steps beyond the incentives and subsidies. Farmers need training and motivational supports for the necessary adaption.
\end{abstract}

Key words: Agricultural productivity, climate change, adaptation, paddy, rainfall variability, Agricultural Development Area (IADA), crop damages, agricultural activities, farm level assessment

\section{INTRODUCTION}

Currently, Malaysia is the 26th largest greenhouse gas emitter in the world (and it is likely to move up the list quickly due to the growth rate of emissions in the country). Due to high greenhouse gas emissions the temperature is projected to rise by about $0.3-4.5^{\circ} \mathrm{C}$. Warmer temperature will cause sea level to rise by about $95 \mathrm{~cm}$ over a hundred-year period. The changes in rainfall may fluctuate from about $-30-+30 \%$. This change will reduce crop yield and cause drought in many areas so that cultivation of some crops such as rubber, oil palm, and cocoa will not be possible (NRS 2001). The projection shows maximum monthly precipitation will increase up to $51 \%$ in Pahang, Kelantan and Terengganu, and the minimum precipitation will decrease by $32-61 \%$ for the entire
Peninsular Malaysia. Consequently, annual rainfall will increase by $10 \%$ in Kelantan, Terengganu, Pahang and North West Coast and decrease by 5\% in Selangor and Johor (NAHRIM 2006). This variation of climatic factors will cause the agricultural system to be vulnerable in Malaysia.

Under current climate change scenario, temperature above $25^{\circ} \mathrm{C}$ may cause decline in grain mass by $4.4 \%$ per $1{ }^{\circ} \mathrm{C}$ rise in temperature (Tashiro and Wardlaw 1989) and grain yield may decline as much as 9.6-10.0\% per $1{ }^{\circ} \mathrm{C}$ rise (Baker and Allen 1993), where average temperature in rice growing areas is about $26^{\circ} \mathrm{C}$. Singh et al. (1996) mentioned that the actual farm yield of paddy rice in Malaysia vary from 3-5 tons per hectare, when the potential yield is 7.2 tons. They also mentioned that there is a decline of rice yield between $4.6-6.1 \%$ per $1{ }^{\circ} \mathrm{C}$ temperature increase under

Corresponding Author: Md. Mahmudul Alam, Department of Environment and Development (LESTARI), University Kebangsaan Malaysia (UKM), Selangor, Malaysia 
the present $\mathrm{CO}_{2}$ level, but a doubling of $\mathrm{CO}_{2}$ concentration (from present level of $340-680 \mathrm{ppm}$ ) may offset the detrimental effect up to $4{ }^{\circ} \mathrm{C}$ temperature increase on rice production in Malaysia. In a recent study it has been found that a $1 \%$ increase in temperature will lead to a $3.44 \%$ decrease in current paddy yield and $0.03 \%$ decrease in paddy yield in next season. At $1 \%$ increase in rainfall will lead to $0.12 \%$ decrease in current paddy yield and $0.21 \%$ decrease of paddy yield in next season (Alam et al., 2010).

Tisdell (1996) mentioned that rainfall variability increases the level of environmental stress that affects the capability of the system to maintain productivity. It is projected that any change in rainfall, both positive and negative, by more than only $0.4 \%$ by 2020 will cause decline in yield of paddy production in Malaysia (NRS 2001). Alam et al. (2011) mentioned that total yearly rainfall in Malaysia is increasing and its monthly variation is too high. The effect of lower rainfall can be checked through proper irrigation system, but the opposite phenomenon of over rainfall for any particular time, especially at the end of the crop cycle or at the maturity period that causes serious damages to crops, is absolutely uncontrollable.

The climatic factors affect, directly or indirectly, the social and economic sustainability of the farmers. Climate changes cause crop damages, low productivity and high production cost that lead to income losses to farmers, increases their poverty level, and increase their seasonal unemployment rate (Alam and Siwar 2009; Siwar et al., 2009a, 2009b). As farmers are dependent on agriculture, when the profitability and quantity of agricultural production decline, their income declines. In Malaysia, the most possible vulnerable states in terms of poverty rates are Sabah $(23 \%)$, Terengganu (15.4\%), Kelantan (10.6\%), Sarawak (7.5\%), Kedah (7\%), Perlis (6.3\%) and Perak (4.9\%), where the projected temperature and rainfall changes are also very high (Malaysia 2006, NAHRIM 2006). It is also observed that the most vulnerable groups of people are the poor engaged in agricultural activities and having relatively larger number of household members (NRS 2001).

Adaptation strategies for the vulnerable groups are crucial because failure to adapt could lead them suffer from "significant deprivation, social disruption and population displacement and even morbidity and mortality" (Downing et al., 1997). The most critical problem is to identify the appropriate adaptation policies that favour the most vulnerable groups. Policy makers should be mindful of the fact that adaptation strategies for climate change may not ensure equal benefits for all areas and groups of people; and a win- win situation among stakeholders is unlikely. In many cases it is faced with situations of conflicting interest among groups. The Second National Agricultural Policy (1992-1997), revised in 1998, and the Third National Agricultural Policy (1998-2010) have recognised this fact. Provisions of necessary incentives and initiatives have been incorporated in these plans to achieve the goal of maximizing income of the stakeholders through optimal utilization of resources. This study is an attempt to measure the influence of external supports like government subsidy on fertilizer, training and other support programs, by government and NGOs, etc., on farmers' adaptability to climate changes in the country

\section{MATERIALS AND METHODS}

To determine the climate change adaptation of the farmers in Malaysia, this study mostly relies on primary data that were collected through a survey on paddy farmers in the Integrated Agricultural Development Area (IADA), North-West Selangor, Malaysia. A structured questionnaire was used to collect data from the sample farmers by the regular IADA enumerators under the direct supervision of IADA officials. IADA in West Selangor consists of eight areas having 10,300 total recorded paddy farmers. Of them, a sample of 198 farmers were selected for the study. These 198 farming households have 577.53 ha of land area for paddy cultivation. The samples were drawn randomly from the 8 areas proportionately based on size of their land areas.

To determine the relationships between the adaptation ability of the farmers and currently available external supports, this study runs ordered dependent regression/ordinal regression:

$$
\mathrm{Q}_{1}=\beta_{1} \mathrm{~V}_{1}+\beta_{2} \mathrm{~V}_{2}+\beta_{3} \mathrm{~V}_{3}+\beta_{4} \mathrm{~V}_{4}+\varepsilon_{\mathrm{i}}
$$

Here:

$\mathrm{Q}_{1}=$ Farmers' capability to adapt with climate change (ordinal data)

$\mathrm{V}_{1}=$ Government supports are enough to cope with climate change effect (ordinal data)

$\mathrm{V}_{2}=\mathrm{NGO}$ (non-governmental organization) supports are enough to cope with climate change effect (ordinal data)

$\mathrm{V}_{3}=$ Other agencies' supports are enough to cope with climate change effect (ordinal data)

$\mathrm{V}_{4}=$ Market support as availability of additional fertilizers in the market (ordinal data)

$\beta=$ Coefficient of Respective Explanatory Variable

$\varepsilon_{\mathrm{i}}=$ Independent and identically distributed random variables 
Am. J. Environ. Sci., 7 (2): 178-182, 2011

Table 1: Available External Supports for Adaptation to Climate Change

\begin{tabular}{|c|c|c|c|c|c|c|c|c|c|}
\hline \multirow[b]{2}{*}{ Types of supports } & \multicolumn{5}{|c|}{ Observation scale* } & \multirow{2}{*}{$\begin{array}{l}\text { Average } \\
\text { Value } \\
\text { of Scale }\end{array}$} & \multirow[b]{2}{*}{ S.D. } & \multirow{2}{*}{$\begin{array}{l}\text { Agreed } \\
\text { (4 and 5) } \\
\text { Respondent }\end{array}$} & \multirow{2}{*}{$\begin{array}{l}\text { Disagreed } \\
(1 \text { and } 2) \\
\text { Respondent }\end{array}$} \\
\hline & 1 & 2 & 3 & 4 & 5 & & & & \\
\hline $\begin{array}{l}\text { Government Supports are Enough } \\
\text { to Cope the Climate Change Effect }\end{array}$ & $63.0 \%$ & $189.1 \%$ & $5829.3 \%$ & $4422.2 \%$ & $7236.4 \%$ & 3.8 & 1.12 & $11658.6 \%$ & $8212.1 \%$ \\
\hline $\begin{array}{l}\text { NGO Supports are Enough to } \\
\text { Cope the Climate Change Effects }\end{array}$ & $105.1 \%$ & $3015.2 \%$ & $5427.3 \%$ & $4321.7 \%$ & $6130.8 \%$ & 3.58 & 1.21 & $10452.5 \%$ & $9420.2 \%$ \\
\hline $\begin{array}{l}\text { Other Agencies' Supports are Enough } \\
\text { to Cope the Climate Change Effects }\end{array}$ & $52.5 \%$ & $189.1 \%$ & $7738.9 \%$ & $5728.8 \%$ & $4120.7 \%$ & 3.56 & 1.00 & $9849.5 \%$ & $10011.6 \%$ \\
\hline $\begin{array}{l}\text { Free Fertilizer from Government is } \\
\text { Enough for Production of Paddy }\end{array}$ & $63.0 \%$ & $157.6 \%$ & $2814.1 \%$ & $6231.3 \%$ & $8743.9 \%$ & 4.06 & 1.08 & $14975.3 \%$ & $4910.6 \%$ \\
\hline $\begin{array}{l}\text { Additional Fertilizers are available } \\
\text { to buy from market }\end{array}$ & $136.6 \%$ & $2010.1 \%$ & $4623.2 \%$ & $5527.8 \%$ & $6432.3 \%$ & 3.69 & 1.21 & $11960.1 \%$ & $7916.7 \%$ \\
\hline
\end{tabular}

*Scale: 1 = strongly disagree, 2 = disagree, 3 = no comment, $4=$ agree, $5=$ strongly agree. Source: Primary survey

Table 2: Statistical Output for Farmers Ability of Adaptation on Currently Available External Supports

\begin{tabular}{lllll}
\hline $\begin{array}{l}\text { Independent } \\
\text { Variables }\end{array}$ & Coefficient & Z-stat & P-value & $\begin{array}{l}\text { Odd } \\
\text { Ratio }\end{array}$ \\
\hline $\mathrm{V}_{1}$ & 0.0247 & 0.089 & 0.782 & 1.025 \\
$\mathrm{~V}_{2}$ & -0.063 & 0.095 & 0.509 & 0.939 \\
$\mathrm{~V}_{3}$ & -0.027 & 0.116 & 0.816 & 0.973 \\
$\mathrm{~V}_{4}$ & $0.153^{\wedge}$ & 0.070 & 0.028 & 1.166 \\
\hline$*, \wedge$ and $\sim$ are significant at the $1 \%, 5 \%$ and $10 \%$ significance level, \\
respectively Note: The Odd ratio is calculated as $\mathrm{e}^{\wedge \beta}$ Source: \\
Statistical output
\end{tabular}

\section{RESULTS}

Most farmers are not aware of the current supports provided by external parties to adapt to climate change. However about $59 \%$ of the farmers believe that government supports are enough to cope properly with climate change and only about $12 \%$ believe the other way (Table 1). About $53 \%$ farmers believe that the supports from NGO are enough to cope with current climate change, and about $50 \%$ believe that the supports from other external agencies are enough to cope with the situation. But interestingly, farmers are not sure about what sort of supports they receive from these agencies. Basically NGOs provide very little supports that include small scale training and experimental plot to test the productivity rate.

According to $75.3 \%$ of the farmers, the fertilizer provided by the government is enough for paddy production. This clearly indicates that most farmers do not use extra fertilizer beyond the fully subsidized quantity. About $60 \%$ farmers knew that beyond the free fertilizer supplied by the government, extra fertilizer was available in the market.

To measure the level of influences of various external factors on the farmers' ability to adapt to climate change, this study runs regression based on ordinal data. But the model with farmers' ability as a function of external supports does not show a good fit, with high p-value (0.27). However, among different types of external supports only market factor shows significant impacts on farmers' capability to adapt to climate change (Table 2). The odd ratio is 1.17 , that mostly is closed to the value of not important. That means farmers' assessment that buying additional fertilizer from market is not important for their current adaptation capability with climate change is found valid at 3\% significance level.

Under the IADA the most influential external supports are same for all the farmers, such as government subsidy and incentives. Therefore, the influences of these supports on farmers' capacity to adoption are the same for all. Only accessibility to the market for buying fertilizer, pesticides and other necessary inputs was not same for all the farmers.

\section{DISCUSSION}

Currently government of Malaysia provides huge amount of subsidy to the paddy producers to encourage paddy cultivation and to ensure more production for increasing the country's self-sufficiency level. The types and contents of these subsidies have been summarized below:

- Input subsidy: 12 bags (20kg each) of compound fertilizer and 4 bags (20kg each) urea fertilizer per hectare- worth Malaysian Ringgit (MYR) 400 and pesticide incentive MYR 200 per hectare

- Price Subsidy: Provided at the selling price- MYR 248.1 per ton

- Rice production incentive: Land preparation/ plowing incentive- MYR 100 per hectare and organic fertilizer $100 \mathrm{~kg}$ per hectare- worth MYR 140 
Am. J. Environ. Sci., 7 (2): 178-182, 2011

Table 3: Government Subsidy (in MYR) for Paddy Sector in Malaysia

\begin{tabular}{|c|c|c|c|c|}
\hline Items & 2004 & 2005 & 2006 & 2007 \\
\hline Subsidy For Paddy Price & $476,628,303$ & $443,218,042$ & $445,749,898$ & $444,000,000$ \\
\hline Paddy Fertilizers & $186,744,867$ & $178,072,073$ & $396,393,001$ & $261,677,743$ \\
\hline Paddy Production Incentive & NA & NA & NA & $67,563,904$ \\
\hline Yield Increase Incentive & NA & NA & NA & $85,434,620$ \\
\hline Paddy Seed Help & NA & NA & NA & $17,000,000$ \\
\hline Diesel Subsidy Scheme & NA & NA & $989,727,418$ & $1,099,000,723$ \\
\hline Petrol & NA & NA & $45,413,959$ & $69,461,384$ \\
\hline Total Subsidy and Incentive & $663,373,170$ & $621,290,115$ & $1,877,284,276$ & $2,044,138,374$ \\
\hline
\end{tabular}

Note: NA for data which were not found available. Source: Agriculture Statistical Handbook 2008

- Yield increase incentive: If producers (farmers) are able to produce 10 tons or more per hectare- they get MYR 650 per ton

- Free supports: Free supports for irrigation, infrastructure and water supply

In order to support the farmers to increase productivity and increase income, government's subsidy for agricultural sector is increasing each year (Table 3). The subsidies for urea and compound fertilizer have been continuing since 1979. The incentives for land preparation and using organic fertilizer have been continuing since 2007. Providing the package of compound and urea fertilizers and pesticide incentives was introduced in 2008 and is still continuing.

\section{CONCLUSION}

Since sustainability of agriculture and farmers' livelihood are strongly dependent on the subsidy and support, and the present level of farmers' adaptability to climate change lacks behind the expected level, there is a need for additional support and efforts by the government and other agencies beyond the strategies of subsidy and incentives. Adaptation to climate change is a broad issue. It needs to be undertaken at many levels, including at the household and community levels. Many of these initiatives are self-funded (Stern 2007). Farmers also need training and conceptual supports.

To enable farmers to adapt to climate change, the very first important step required is to make them aware of future risks of climate change, especially climate change related socioeconomic vulnerabilities. It will help them prepare their mindset to deal with climate change and other socioeconomic stresses and think about how to respond in adverse situations.

Secondly, the production practices of farms and individual farmers need to be kept up to date with the changes in climatic factors. They should also take all precautions and be aware of the uncertainty of low rainfall and heavy rainfall. They must be careful in arranging proper water management, both in terms of irrigation facilities and quick water logout facilities. Apart from that, they also need to understand the importance of proper timing and react quickly at the sight of upcoming rainfall events.

Thirdly, as the supply of irrigation water and changing crop cycle are emerging problems in the IADA area, farmers should be informed about crop rotation, crop portfolio and crop substitutions to address the environmental variations and economic risks associated with climate change. Moreover, they need to utilize land properly and change the locations of crop production, if possible, to cope with extreme cases. Further, they need to adapt to the changing length of growing seasons and associated changes in climate factors.

Finally, the financial management of farms and farmers too need to be secured for a minimum of two seasons so that if crop is damaged in one season, they will be prepared and have the seeds for next season; their ability to bear the cost of another crop production will guarantee their survival financially up to the collection of the new crops. Currently heavy rainfall and storm is a very common phenomenon in the study area. For that reason, farmers should take the initiative for crop sharing, forward rating, hedging and insurance. Farmers also need crop insurance facility, but no such option is currently available. Moreover, they need to take income stabilization programmes, such as portfolio of investment, saving scheme, minimum income protection by government or insurance to reduce the risk of income loss due to changing climatic conditions and variability.

At last, it has been suggested to prepare a planned and proactive adaptation strategy in Malaysia to secure sound functioning of the economic, social and agricultural system.

\section{ACKNOWLEDGEMENT}

We are thankful to Ministry of Science, Technology and Environment of the Government of Malaysia for generously funding the research, under the 
Research University Grant (UKM-GUP-PI-08-34-081). We would also like to thank Dr. Wahid Murad, the University of Adelaide, Australia for his advice and support at various stages of the study.

\section{REFERENCES}

Agriculture Statistical Handbook, 2008. Paddy. Ministry of agriculture. Malaysia. ISSN: 13949721

Alam, M.M. and C. Siwar, 2009. Socioeconomic impacts and vulnerability of climate change on farming community: A study on Malaysian perspective. Proceedings of the 3rd International Conference on Social Sciences and Humanities. Dec 2-3, National University of Malaysia, Malaysia.

Alam, M.M., B. Talib, C. Siwar and M.E. bin Toriman, 2010. The impacts of climate change on paddy production in Malaysia: Case of paddy farming in north west Selangor. Proceedings of the International Conference of the 4th International Malaysia- Thailand Conference on South Asian Studies. Mar 25-26, National University of Malaysia, Malaysia.

Alam, M.M., M.E. bin Toriman, C. Siwar and B. Talib, 2011. Rainfall variation and changing pattern of agricultural cycle. Am. J. Environ. Sci., 7: 82-89. DOI: 10.3844 /ajessp.2011.82.89

Baker, J.T. and L.H. Allen, Jr., 1993. Contrasting crop species responses to $\mathrm{CO}_{2}$ and temperature: Rice, soybean and citrus. Vegetatio, 104: 239-260. http://www.jstor.org/pss/20029749

Downing, T.E., L. Ringius, M. Hulme and D. Waughray, 1997. Adapting to climate change in Africa. Mitig. Adapt. Strateg. Global Change, 2: 19-44.

DOI: 10.1023/B:MITI.0000004663.31074.64

Malaysia, 2006. Ninth Malaysia Plan, 2006-2010. Putrajaya: Economic Planning Unit, pp: 559. (online) http://www.parlimen.gov.my/news/engucapan rmk9.pdf

NAHRIM. 2006. Study of the impact of climate change on the hydrologic regime and water resources of peninsular malaysia, National Hydraulic Research Institute of Malaysia (NAHRIM) and California Hydrologic Research Laboratory (CHRL), Malaysia. (online) http://www.nahrim.gov.my/download/pksa/RegHC M PM Report 9221 06 Ex\%20v1.pdf
NRS, 2001. National response strategies to climate change. Ministry Sci., Technol. Environ., Malaysia. (online) http://gedung.nahrim.gov.my/wapi/mctweb.dll/get Object?MID $=$ WATER $\% 20$ RESOURCES\&Sn $=203$ 8

Singh, S., R. Amartalingam, W.S. Wan Harun and M.T. Islam, 1996. Simulated impact of climate change on rice production in Peninsular Malaysia. Proceeding of the National Conference on Climate Change. pp: 41-49, UPM, Malaysia.

Siwar, C., M.M. Alam, M.W. Murad and A.Q. Al-amin, 2009a. Impacts of climate change on agricultural sustainability and poverty in Malaysia. Proceeding of the $10^{\text {th }}$ International Business Research Conference. Dubai. UAE. Apr 16-17. (online) http://www.wbiconpro.com/15[1].Siwar.pdf

Siwar, C., M.M. Alam, M.W. Murad and A.Q. Al-amin, 2009b. A review of the linkages between climate change, agricultural sustainability and poverty in Malaysia. Int. Rev. Bus. Res. Papers, 5: 309-321 (online) http://www.bizresearchpapers.com/23.\%20Siwar.p df

Stern, N., 2007. The economics of climate change: the stern review. Cambridge University Press: Cambridge. ISBN-13: 9780521700801.

Tashiro, T. and I.F. Wardlaw, 1989. A comparison of the effect of high temperature on grain development in wheat and rice. Annals of Botany 64: 59-65. (online) http://aob.oxfordjournals.org/content/64/1/59.abstr $\underline{\text { act }}$

Tisdell, C., 1996. Economic indicators to assess the sustainability of conservation farming projects: An evaluation. Agriculture, Ecosyst. Environ. 57: 117131. 